\title{
Introducing Fluorescence-Guided Surgery for Pediatric Ewing, Osteo-, and Rhabdomyosarcomas: A Literature Review
}

\author{
Zeger Rijs ${ }^{1, *},+\left(\mathbb{D}\right.$, Bernadette Jeremiasse ${ }^{2, \dagger}{ }^{\dagger}$, Naweed Shifai ${ }^{1}$, Hans Gelderblom ${ }^{3}$, Cornelis F. M. Sier ${ }^{4,5}$, \\ Alexander L. Vahrmeijer ${ }^{4}$, Fijs W. B. van Leeuwen ${ }^{6}$, Alida F. W. van der Steeg ${ }^{2}$ and Michiel A. J. van de Sande ${ }^{1}$ \\ 1 Department of Orthopedic Surgery, Leiden University Medical Center, Albinusdreef 2, \\ 2333 ZA Leiden, The Netherlands; A.N.Shifai@lumc.nl (N.S.); M.A.J.van_de_Sande@lumc.nl (M.A.J.v.d.S.) \\ 2 Department of Surgery, Princess Maxima Center for Pediatric Oncology, Heidelberglaan 25, \\ 3584 CS Utrecht, The Netherlands; B.Jeremiasse-4@prinsesmaximacentrum.nl (B.J.); \\ a.f.w.vandersteeg@prinsesmaximacentrum.nl (A.F.W.v.d.S.) \\ 3 Department of Medical Oncology, Leiden University Medical Center, Albinusdreef 2, \\ 2333 ZA Leiden, The Netherlands; A.J.Gelderblom@lumc.nl \\ 4 Department of Surgery, Leiden University Medical Center, Albinusdreef 2, 2333 ZA Leiden, The Netherlands; \\ C.F.M.Sier@lumc.nl (C.F.M.S.); A.L.Vahrmeijer@lumc.nl (A.L.V.) \\ 5 Percuros BV, 2333 CL Leiden, The Netherlands \\ 6 Interventional Molecular Imaging Laboratory, Department of Radiology, Leiden University Medical Center, \\ Albinusdreef 2, 2333 ZA Leiden, The Netherlands; F.W.B.van_Leeuwen@lumc.nl \\ * Correspondence: Z.Rijs@lumc.nl; Tel.: +31-641-637-074 \\ + These authors contributed equally to this work.
}

Citation: Rijs, Z.; Jeremiasse, B.; Shifai, N.; Gelderblom, H.; Sier, C.F.M.; Vahrmeijer, A.L.; van Leeuwen, F.W.B.; van der Steeg, A.F.W.; van de Sande, M.A.J. Introducing Fluorescence-Guided Surgery for Pediatric Ewing, Osteoand Rhabdomyosarcomas: A Literature Review. Biomedicines 2021, 9, 1388. https://doi.org/10.3390/ biomedicines 9101388

Academic Editor: Emmy D.G. Fleuren

Received: 23 July 2021

Accepted: 1 October 2021

Published: 4 October 2021

Publisher's Note: MDPI stays neutral with regard to jurisdictional claims in published maps and institutional affiliations.

Copyright: (c) 2021 by the authors Licensee MDPI, Basel, Switzerland. This article is an open access article distributed under the terms and conditions of the Creative Commons Attribution (CC BY) license (https:// creativecommons.org/licenses/by/ $4.0 /)$

\begin{abstract}
Sarcomas are a rare heterogeneous group of malignant neoplasms of mesenchymal origin which represent approximately $13 \%$ of all cancers in pediatric patients. The most prevalent pediatric bone sarcomas are osteosarcoma (OS) and Ewing sarcoma (ES). Rhabdomyosarcoma (RMS) is the most frequently occurring pediatric soft tissue sarcoma. The median age of OS and ES is approximately 17 years, so this disease is also commonly seen in adults while non-pleiomorphic RMS is rare in the adult population. The mainstay of all treatment regimens is multimodal treatment containing chemotherapy, surgical resection, and sometimes (neo)adjuvant radiotherapy. A clear resection margin improves both local control and overall survival and should be the goal during surgery with a curative intent. Real-time intraoperative fluorescence-guided imaging could facilitate complete resections by visualizing tumor tissue during surgery. This review evaluates whether non-targeted and targeted fluorescence-guided surgery (FGS) could be beneficial for pediatric OS, ES, and RMS patients. Necessities for clinical implementation, current literature, and the positive as well as negative aspects of non-targeted FGS using the NIR dye Indocyanine Green (ICG) were evaluated. In addition, we provide an overview of targets that could potentially be used for FGS in OS, ES, and RMS. Then, due to the time- and cost-efficient translational perspective, we elaborate on the use of antibody-based tracers as well as their disadvantages and alternatives. Finally, we conclude with recommendations for the experiments needed before FGS can be implemented for pediatric OS, ES, and RMS patients.
\end{abstract}

Keywords: fluorescence-guided surgery; osteosarcoma; Ewing sarcoma; rhabdomyosarcoma

\section{Introduction}

Sarcomas are a rare heterogeneous group of malignant neoplasms of mesenchymal origin representing approximately $13 \%$ of all cancers in pediatric patients [1,2]. Sarcomas are generally subdivided into bone sarcomas and soft tissue sarcomas (STS) [3]. The most prevalent pediatric bone sarcoma is osteosarcoma (OS), with an annual incidence of 8-11 cases per million at 15-19 years of age [4], followed by Ewing sarcoma (ES), with an annual incidence of 9-10 cases per million at 10-19 years of age [5]. Rhabdomyosarcoma (RMS) is the most frequently occurring STS in the pediatric population, representing 
approximately $40 \%$ of all STS with an annual incidence of five cases per million below the age of 20 [6].

OS, ES, and RMS are commonly treated with multimodality therapy comprising surgery and (neo)adjuvant chemotherapy with or without radiotherapy [7-11]. For surgery, the current standard has been moved from amputations (with radical or wide margins) towards limb-salvage surgery with free margins [12,13]. Hence, the accuracy of surgical resection is an important prognostic factor for local recurrence-free and overall survival rates $[11,14,15]$. Although preoperative radiological imaging aids surgical planning, intraoperative margin assessment can be challenging, particularly when tumor tissue is surrounded by vital neurovascular structures or when tumors are located within deeper and more complex anatomical sites such as the pelvis or the head and neck region. Unfortunately, inadequate or positive resection margins are described in $10-40 \%$ of OS cases, $15-30 \%$ of ES cases, and in 20-30\% of RMS cases [12,16-20]. Differences in local recurrence rates, 5-year overall survival, or 5-year event-free survival between adequate (defined as radical or wide) and inadequate (defined as marginal or intralesional) resection margins range from 20 to $25 \%$ in favor of adequate resection margins [11,12,15,16]. Apart from increasing local recurrence-free and overall survival rates, complete resections help reduce total dosages of adjuvant chemo- and or radiotherapy [11,17]. This is particularly relevant for pediatric patients as survivors face risks of common cancer treatmentrelated side effects, such as impaired growth and development, organ dysfunction, and secondary malignancies [21,22].

The increased local recurrence and decreased survival rate on the one hand and the increased risk of treatment-related side effects on the other hand indicate the necessity for adequate surgical resections. The real-time intraoperative visualization of malignancies could improve resection accuracy by aiding the surgeon discriminate between healthy and malignant tissue. Fluorescence-guided surgery (FGS) is one of the promising technological advances facilitating the visualization of tumors in real-time during surgery [23,24].

FGS exploits the advantages of near-infrared-I (NIR-I) light (750-1000 nm) or NIR-II light (1000-1700 nm), which have a tissue penetration of several millimeters to a centimeter deep [25]. Another advantage of NIR light is that almost no autofluorescence is exhibited in the NIR spectrum by biological tissue, which maximizes the potential tumor-to-background ratio of fluorescence when visualizing tumors [26,27]. In addition, the surgical field is generally not altered by NIR light, as the human eye is insensitive to NIR wavelengths [28]. The two main requirements for FGS comprise a fluorescent tracer and a dedicated camera system which captures light emitted by the tracer upon excitation with an appropriate light source [26]. FGS camera systems are manufactured by several companies; systems for open-, endoscopic- and/or robotic surgery were developed and are currently available [29].

Depending on which fluorescent tracers are applied, both non-targeted and targeted FGS is possible [28,30]. Indocyanine green (ICG) is the most used and investigated fluorescent dye for non-targeted FGS. Its benefits have been shown, amongst others, in assessing perfusion, identifying liver metastases and visualizing sentinel lymph nodes [23,31]. Targeted tracers contain fluorophores conjugated to cancer-specific targeting moieties such as antibodies, peptides or small molecule inhibitors [32,33]. While FGS has been investigated with promising results in various types of malignancies, information regarding its application in pediatric sarcomas such as OS, ES, and RMS is relatively scarce [34]. This review evaluates whether non-targeted and targeted FGS strategies hold promise for OS, ES, and RMS surgery. Necessities for clinical implementation, current literature, and the disadvantages of non-targeted FGS using ICG versus targeted FGS are evaluated. In addition, we provide an overview of tumor receptors that could be targeted in OS, ES, and RMS. Then, due to the time- and cost-efficient translational perspective, we elaborate on the use of antibody-based tracers as well as their disadvantages and alternatives. Lastly, we conclude with recommendations for the experiments needed before FGS can be implemented for pediatric OS, ES, and RMS patients. 


\section{Non-Targeted Fluorescence-Guided Surgery for OS, ES, and RMS Using Indocyanine Green}

The indocyanine fluorescent dye ICG is already implemented for FGS in clinics. Currently, ICG is registered under two names: ICG-GREEN (Food and Drug Administration; FDA, Washington, DC, USA) and Verdye (European Medicines Agency; EMA, Amsterdam, The Netherlands. It can be administered with a maximum intravenous dose of $1.25 \mathrm{mg} / \mathrm{kg}$ for children aged 0-2 years, $2.5 \mathrm{mg} / \mathrm{kg}$ for children aged 2-11 years, and $5 \mathrm{mg} / \mathrm{kg}$ for children older than 11 years [35]. Once ICG is administered, it binds to plasma proteins, thereby increasing its hydrodynamic diameter to approximately $10 \mathrm{~nm}$ [36]. These complexes accumulate in tumors due to their leaky vascular capillaries, referred to as the enhanced permeability and retention (EPR) effect [37]. Once in the tumor, these molecules remain there due to their general characteristics such as size, shape, charge, and polarity, rather than tumor cell-specific binding.

ICG has been shown to be safe and accurate for the intra-operative visual identification of several tumor types in adults, such as colorectal liver metastasis, hepatocellular carcinoma, and brain tumors [27].

Although not applied for sarcoma resections, there is experience with ICG-guided surgery for pediatric patients [38]. Esposito et al. reported their results in 76 laparoscopic and/or robotic procedures (40 left varicocelectomies, 13 renal procedures, 12 cholecystectomies, 5 tumor excisions, 3 lymphoma excisions, 3 thoracoscopic procedures, 2 lobectomies, and 1 lymph node biopsy). They concluded that ICG-guidance is useful because it is easy to apply, safe, and allows for the better identification of anatomical structures as well as easier surgical dissection or resection in challenging cases. The technology is now also used in trial settings for pediatric surgical oncology [39].

\subsection{Indocyanine Green for Sarcoma Resections}

Only one study describes the use of ICG for various sarcoma resections in 26- to 79-year-old adults [40]. They included eleven patients, among which were one OS patient and one pleomorphic RMS patient who received $75 \mathrm{mg}$ ICG $16-24 \mathrm{~h}$ before surgery. All sarcomas contained a fluorescent signal, except for the OS patient. However, this tumor was more than $90 \%$ necrotic due to neoadjuvant treatment. For the two patients, including the RMS patient, ICG fluorescence was of definite guidance, leading to extended tissue resection to improve the resection margin.

Multiple studies describe the use of ICG for the resection of pulmonary metastases, which also frequently occur in young sarcoma patients [41]. Predina et al. administered $5 \mathrm{mg} / \mathrm{kg}$ ICG $24 \mathrm{~h}$ preoperatively to 30 adult patients (23-79 years) suspected of pulmonary sarcoma metastases, including six OS patients, four ES patients, and two RMS patients [42]. They found that during thoracotomy or thoracoscopy, respectively, 88 and $89 \%$ of pulmonary sarcoma metastases showed fluorescence. Non-fluorescent (tumor-to-background ratio $<2$ ) lesions were located deeper than $2 \mathrm{~cm}$, corresponding with the maximum tissue penetration of light at this wavelength $(<1 \mathrm{~cm})$. Furthermore, ICG fluorescence identified additional occult lesions among which $88 \%$ were confirmed metastases and the others lymphoid aggregates. In addition, Keating et al. administered $5 \mathrm{mg} / \mathrm{kg}$ ICG $24 \mathrm{~h}$ preoperatively to eight adult patients (exact age not described) with the suspected pulmonary metastasis of various primary tumors including two OS patients [43]. Intraoperative thoracoscopic ICG fluorescence identified six of the eight preoperatively localized lesions. The missed nodules were the deepest from the pleural surface on the CT scan $(1.8 \mathrm{~cm}$ and $1.6 \mathrm{~cm})$. One additional nodule was identified by ICG fluorescence, which was a metastasis as confirmed by pathology. In addition, Okusanya et al. administered $5 \mathrm{mg} / \mathrm{kg}$ ICG $24 \mathrm{~h}$ preoperatively to 18 adult patients (29-79 years) with solitary pulmonary nodules that required resection [44]. Intraoperative thoracotomic ICG fluorescence identified 16/18 primary nodules with a maximum depth of $1.3 \mathrm{~cm}$ from the pleural surface. The two non-fluorescent nodules were identified by manual palpation and visual inspection. Additionally, ICG fluorescence 
also identified five additional subcentimeter nodules (minimum size $0.2 \mathrm{~cm}$ ) of which two were metastatic sarcomas and three were metastatic adenocarcinomas.

Despite these results, it must still be assessed for which pediatric sarcoma types—often biologically different from sarcomas in adult patients-the application of non-targeted FGS using ICG could be useful [45]. St. Jude Children's Research Hospital is currently performing a large phase 1 single-center trial for pediatric oncology patients, which will include 39 OS, $39 \mathrm{ES}$, and 39 RMS patients. The results of this trial (scheduled end-date December 2022) will represent a large step forwards in unraveling whether FGS using ICG could be of additive value for pediatric OS, ES, and RMS patients.

\subsection{Pros and Cons of Fluorescence-Guided Surgery and Indocyanine Green for Patient and Surgeon}

In general, FGS has several advantages when compared to other intra-operative detection methods. As mentioned in the introduction, it has a tissue penetration of several millimeters up to a centimeter, depending on the tissue type. It is relatively harmless compared with intraoperative computed tomography or radio-active agents. In addition, NIR-light emitted by NIR fluorophores is invisible to the naked eye and thus does not contaminate the surgical field nor does it leave long lasting tattoos, as is the case with blue dye [46]. Moreover, unlike the intraoperative histopathological examination of the surgical margin, FGS does not interrupt the surgical workflow [47]. Additional advantages have been reported for ICG specifically. ICG is relatively cheap and immediate reinjections are possible to assess perfusion when the fluorescent signal has diminished [48]. Furthermore, ICG is shown to be safe with only minor risks of adverse events, i.e., a risk of less than 1 in 10,000 of an anaphylactic reaction. Finally, ICG for FGS is generally given $24 \mathrm{~h}$ preoperatively, which is usually the moment patients are admitted to the hospital before undergoing tumor resection.

However, the general disadvantages of FGS include an additional investment for a dedicated camera system which may not be affordable for every hospital. In addition, bone tumors and nodules located deeper than $1 \mathrm{~cm}$ could still be missed due to the limited depth penetration of NIR fluorescence $[25,49]$. For the use of ICG, additional caveats and disadvantages have been described. First, there is not much scientific evidence regarding tumor-specific resections. Therefore, there is no proof that the use of ICG for tumor resections is beneficial for patient outcomes such as functional outcome, diseasespecific local recurrence, and/or disease-specific survival. Secondly, since ICG is dissolved in a solution containing iodine, its application is contraindicated in patients with an iodine allergy or thyroid abnormalities, such as a clinical manifest hyperthyroidism or autonomous thyroid adenoma iodine [50]. In addition, patients with renal insufficiency might have an increased risk of anaphylactic reactions. Therefore, the advantages of ICG for patients with renal insufficiency (estimated GFR of $<30 \mathrm{~mL} / \mathrm{min} / 1.73 \mathrm{~m}^{2}$ ) should be carefully weighed against the risk of potential adverse events. Additionally, for patients that would not be admitted $24 \mathrm{~h}$ preoperatively, the intravenous administration of ICG may be a burden from a logistical and financial point of view. Lastly, ICG fluorescence is associated with the EPR effect, which is known to be influenced by many factors, such as the tumor type, size, presence of necrosis, location, inflammation, and vascular mediators. Therefore, the signal intensity of ICG is unpredictable. False negativity could occur in cases with very small nodules, nodules with extensive necrosis or minimally viable tissue. In addition, false positivity could occur as well, for example in tissue with reactive changes or high levels of vascular permeability mediators such as bradykinin and prostaglandin [51,52].

\section{Targeted Fluorescence-Guided Surgery for OS, ES, and RMS}

Tumor-specific FGS does not depend on the tumor microenvironment, such as ICG with the EPR effect, but depends on tracers that bind to tumor-specific receptors. To select tumor-specific receptors that are appropriate for FGS, several characteristics have to be evaluated. The most important parameters for target selection are the following: targets should have been assessed in a large amount of tumor samples as this represents 
a measurement of evidence; a high percentage of tumor samples should actually express the tumor-specific target; when a tumor is positively stained, a high percentage of tumor cells should express the target; there should be a diffuse expression pattern of the tumorspecific target throughout the whole tumor and not in specific parts; the receptor should be preferably located on the cell surface of malignant cells to permit direct targeting with the possibility of internalization for a long-lasting signal; the tumor-specific receptor is still present after neoadjuvant therapy, which is important because neoadjuvant therapy is standard treatment for OS, ES, and non-pleiomorphic RMS; and the expression of the target should be absent or substantially less in adjacent normal tissue to adequately differentiate tumor from healthy tissue (Table 1).

Table 1. Important parameters for target selection.

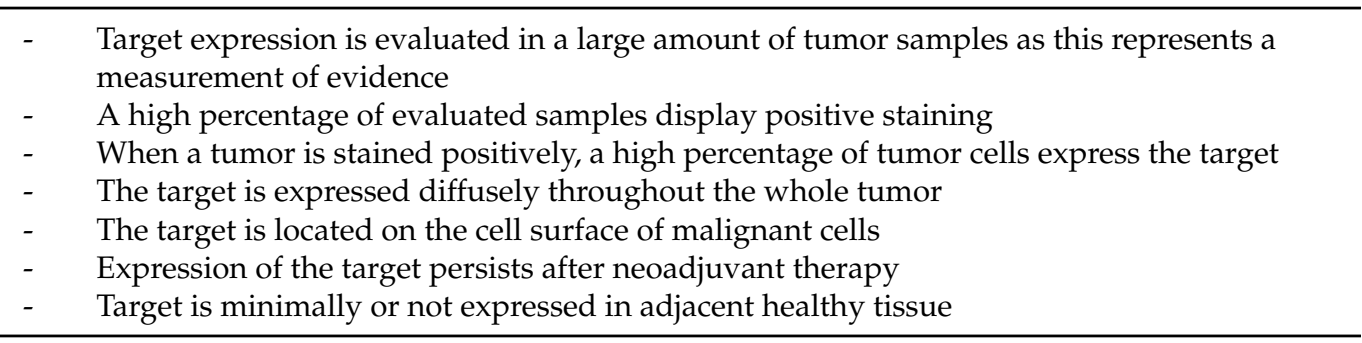

\subsection{Promising Tumor-Specific Fluorescent Agents for ES, OS, and RMS}

Bosma et al. systematically reviewed 86 articles that studied 47 targets for FGS in primary ES tumors [53]. Cell surface protein expression was evaluated by Western blot or immunohistochemistry, and in descending order, the following nine targets were selected as the most promising for FGS: Cluster of differentiation 99 (CD99), C-X-C chemokine receptor type 4 (CXCR4), occludin, neuropeptide receptor Y1 (NPY1), LINGO-1, insulin like growth factor 1 receptor (IGF-1R), claudin-1, c-kit (also known as cluster of differentiation 117; CD117), and NOTCH receptor. Except for occludin, all previously mentioned targets have clinically available targeting moieties which in principle can be used for FGS in ES [53]. Still, further immunohistochemical studies that include both tumor and adjacent normal tissue should be performed to choose the most optimal candidate. In addition, more recent diagnostic markers, such as NKX2.2, could also be evaluated for their potential in FGS [54]. Nevertheless, the first steps were made to explore the promising targets for FGS in ES patients.

Systematic reviews selecting promising tumor-specific targets for OS and RMS have not been published to date. Therefore, we evaluated the literature to identify targets for FGS of OS and RMS. First, clinically available antibodies and their respective targeting antigens for these tumor types were identified from PubMed and clinicaltrials.gov (Supplementary Tables S1 and S2). This search was restricted to therapeutic antibodies which have been previously or are currently evaluated in clinical trials because these antibodies can be relatively time- and cost-efficiently modified into fluorescent tracers [24,55]. Second, PubMed searches were performed to find important information for target selection (Appendix A). Here, we considered targets promising for FGS if the expression was evaluated in at least 20 tissue samples for a tumor subtype and more than $50 \%$ of the samples stained positive. When targets did not meet these two requirements, they were considered less promising. Although the remaining criteria in Table 1 are indeed important, solely data on sample size and the percentage of positive samples were available for each target. Therefore, only these two criteria could be assessed to determine the most promising targets.

Based on this strategy, the following seven targets were considered candidates for the FGS of OS: AXL receptor tyrosine kinase (AXL), B7 homolog 3 (B7-H3), cluster of differentiation 47 (CD47), disialoganglioside GD2 (GD2), transmembrane nonmetastatic melanoma protein B (gpNMB), IGF-1R, and vascular endothelial growth factor A (VEGF-A). 
Interestingly, all promising targets were demonstrated to internalize upon binding with an antibody (-derivative) in other tumor types, except for VEGF-A as it is not a cell-surface expressed receptor [56-60]. In contrast, three targets with clinically therapeutic antibodies were considered less promising for FGS. These were: human epidermal growth factor receptor 2 (HER2), programmed death-ligand 1 (PD-L1), and tumor endothelial marker 1 (TEM1) (Table 2).

An important nuance is that HER2, PD-L1, and VEGF-A were investigated in a large number of (pre)clinical studies. The remaining targets were evaluated considerably less. Publication bias might have had an impact on the published results concerning these targets.

For RMS, less literature is published regarding the expression of targets with clinically available antibodies. Based on the criteria in Table 1, three promising targets were selected: the cluster of differentiation 56 (CD56), IGF-1R, and VEGF-A (Table 3). Of these, IGF-1R has been demonstrated to internalize [57]. Interestingly, all studies are mainly investigated alveolar RMS and/or embryonal RMS. These are the subtypes which most frequently occur in pediatric RMS patient. In contrast, B7-H3 and TEM1 were considered less promising for FGS in RMS (Table 3).

Combining the results from the systematic review by Bosma et al. with Tables 2 and 3 , IGF-1R seems the only target that is simultaneously promising for OS, ES, and RMS [53]. This suggests that a fluorescent dye conjugated to a clinically available antibody targeting IGF-1R (Supplementary Tables S1 and S2) could be applicable for the majority of pediatric OS, ES, and RMS sarcoma patients.

\subsection{Obstacles Regarding the Selection of Tumor-Specific Targets for Fluorescence-Guided Surgery}

Data presented in the previous paragraphs are based on immunohistochemical studies which have been performed for other purposes than FGS. Therefore, the interpretation of the results of those studies for FGS purposes should be done with caution. The comparison of immunohistochemical studies is complicated as large inconsistencies in reported target expression exist between various studies. This can be due to the application of different antibodies for the same target but against various epitopes, due to differences in staining protocols, or due to inter-/intra-tumoral heterogeneity [61-63]. Moreover, the use of immunohistochemical evaluation in formalin-fixed paraffin-embedded (FFPE) samples with the intention to target the same protein on living cells for imaging purposes has multiple disadvantages. A prominent cause of the loss of antigenicity is formalin fixation which generates crosslinks between adjacent proteins that result in the steric interference of antibody binding to the respective epitope [64]. Furthermore, bone tissue requires decalcification, which is known to impair antigen retrieval and alters the immunohistochemical staining intensity $[65,66]$.

To overcome the aforementioned obstacles, studies with the aim of target evaluation for FGS should be performed. Here, the staining of undecalcified fresh frozen sections (FFS) could be advantageous $[62,67,68]$. Unfortunately, many clinical FFS specimens are not readily available in this form, which complicates acquiring large sample sizes; storage is expensive and requires an advanced infrastructure; and tissue morphology is less well preserved over time compared to FFPE [69-71].

\subsection{Translational Perspective of Targeted Fluorescence-Guided Surgery for OS, ES, and RMS}

The previous sections provide an overview of potential tumor-specific targets for OS, ES, and RMS. As fluorophores by themselves generally lack tumor specificity, they could be conjugated to a targeting moiety such as a monoclonal antibody, a peptide, or small molecule inhibitors [32]. Antibody-based tracers are most often investigated for FGS as monoclonal therapeutic antibodies against a wide variety of targets are readily available and can be repurposed for FGS by fluorophore conjugation [26]. For this purpose, various fluorophores are available, and some are clinically approved, paving the way for implementing FGS to optimize surgical oncology [29]. 
Several therapeutic antibodies binding to candidate targets for OS, ES, and RMS are available (Supplementary Table S1). Additional therapeutic antibodies that are currently being investigated in clinical trials are described in Supplementary Table S2. Because most therapeutic antibodies are human or have been humanized, they are reported with tolerable safety profiles. Moreover, it should be noted that doses of antibodies injected for FGS are substantially (approximately 10-100 $\times$ ) lower compared to therapeutic doses. Consequently, the serum concentration of the antibody (conjugated to a fluorophore) is lower when used for FGS and little or no toxicity is expected [72]. Moreover, some of the therapeutic antibodies evaluated for therapy in pediatric OS, ES, and RMS patients have already been repurposed for FGS and accurately visualized tumor tissue in other cancer types [73-77]. Although it is important to notice that HER2 is considered a less promising target in OS (Table 2), Trastuzumab-IRDye800CW targeting HER2 has imaged breast cancer and could be tested in OS patients as well [75]. More encouragingly, Bevacizumab-IRDye800CW targeting VEGF-A was successful for FGS in adult soft tissue sarcoma patients [77]. Due to the presence of VEGF-A in pediatric OS and RMS (Tables 2 and 3), testing BevacizumabIRDye $800 \mathrm{CW}$ is a relatively straightforward option which could pave the road towards the clinical implementation of FGS in pediatric OS and RMS patients. 
Table 2. Characteristics of targets evaluated for fluorescence-guided surgery in osteosarcoma.

\begin{tabular}{|c|c|c|c|c|c|c|c|}
\hline Targets & Tissue Samples & \% Positive Samples & $\%$ Positive Cells & $\begin{array}{l}\text { Expression Altered after } \\
\text { Neo-Adjuvant Therapy }\end{array}$ & (Adjacent) Healthy Tissue & Internalization ${ }^{1}$ & References \\
\hline \multicolumn{8}{|c|}{ Promising targets ${ }^{2}$} \\
\hline AXL & $40 \mathrm{TMA}(\mathrm{RM})+6 \mathrm{~TB}$ & $75-83 \%$ & N.D. & N.D. & $\begin{array}{l}\text { TMA (RM): } 20 \% \text { of } 40 \\
\text { weakly positive }\end{array}$ & Yes & {$[58,78,79]$} \\
\hline B7-H3 & $61 \mathrm{PR}$ & $92 \%$ & Median: 90\% & N.D. & $\begin{array}{l}61 \text { cases matched healthy tissue } \\
\text { negative staining }\end{array}$ & Yes & {$[60,80]$} \\
\hline $\mathrm{CD} 47$ & $20 \mathrm{RM}$ & $85 \%$ & N.D. & N.D. & $\begin{array}{l}\text { WB: substantially lower protein } \\
\text { levels in } 6 \text { healthy tissues } \\
\text { compared to tumor tissue }\end{array}$ & Yes & {$[57,81]$} \\
\hline GD2 & 55 TMA (from TB, PR, RR) & $95-100 \%$ & N.D. & $\begin{array}{l}\text { No, target expression } \\
\text { remains }\end{array}$ & N.D. & Yes & {$[59,82,83]$} \\
\hline gpNMB & 67 TMA (from TB, PR, RR) & $93 \%$ & $\begin{array}{l}>66 \% \text { positive tumor } \\
\text { cells in } 37 \% \text { of samples }\end{array}$ & Probably not ${ }^{3}$ & N.D. & N.D. & [84] \\
\hline IGF-1R & $84 \mathrm{TS}$ & $86 \%$ & $\begin{array}{c}50-75 \% \text { positive cells in } \\
24 \% \text { of samples }\end{array}$ & N.D. & $\begin{array}{l}\text { WB: substantially lower protein } \\
\text { levels in healthy tissue } \\
\text { compared to tumor tissue }\end{array}$ & Yes & {$[56,85]$} \\
\hline VEGF-A & $\begin{array}{c}466 \text { TMA (TB + PR + RR) + } \\
\text { TB + PR + RR }\end{array}$ & $\begin{array}{l}\text { Average of } 59.9 \% \\
\text { (range } 15-96 \%)\end{array}$ & $\begin{array}{l}>50 \% \text { in } 11-38.8 \% \text { of } \\
\text { samples }\end{array}$ & $\begin{array}{l}\text { Uncertain, varying results } \\
\text { in different studies }\end{array}$ & N.D. & No & [86-98] \\
\hline \multicolumn{8}{|c|}{ Less promising targets ${ }^{2}$} \\
\hline HER2 & $\begin{array}{c}1 \text { systematic review: } 934 \mathrm{~TB} \\
+\mathrm{PR}+\mathrm{RR}\end{array}$ & $\begin{array}{c}\text { Average } 42 \% \text { (range) } \\
13-60 \%\end{array}$ & $<50 \%$ & N.D. & $\begin{array}{l}10 \text { healthy bone samples from } \\
\text { fractures were negative }\end{array}$ & Yes & {$[87,99-101]$} \\
\hline PD-L1 & $\begin{array}{l}418 \text { TMA (TS) + TB } \\
+ \text { PR + RR }\end{array}$ & $\begin{array}{l}\text { Average of } 32.5 \% \\
\text { (range } 0-85 \%)\end{array}$ & $<25 \%^{4}$ & Yes, decreased ${ }^{5}$ & N.D. & Yes & {$[66,102-110]$} \\
\hline TEM1 & 11 TS & $63.6 \%$ & N.D. & N.D. & N.D. & Yes & {$[111,112]$} \\
\hline
\end{tabular}

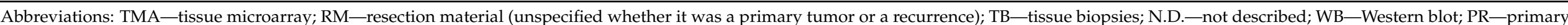

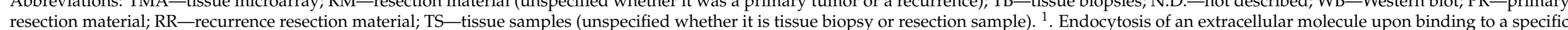

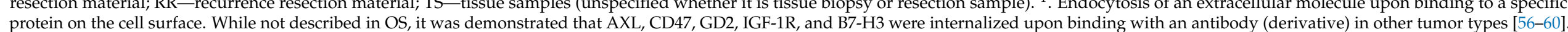

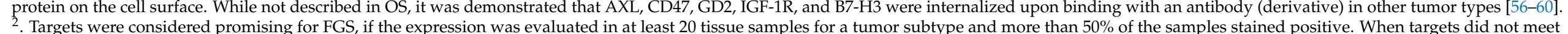

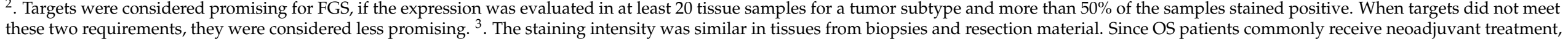

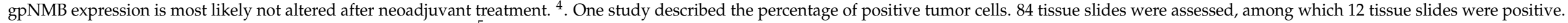

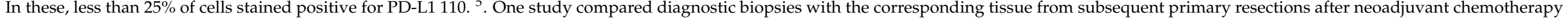
(methotrexate, cisplatin, and doxorubicin). While 53\% of pre-neoadjuvant treatment biopsies stained positive for PD-L1, none of the resection samples did [65]. 
Table 3. Characteristics of targets evaluated for fluorescence-guided surgery in rhabdomyosarcoma.

\begin{tabular}{|c|c|c|c|c|c|c|c|}
\hline Targets & Tissue Samples & $\%$ Positive Samples & $\%$ Positive Cells & $\begin{array}{l}\text { Expression Altered after } \\
\text { Neo-Adjuvant Therapy }\end{array}$ & (Adjacent) Healthy Tissue & Internalization ${ }^{1}$ & References \\
\hline \multicolumn{8}{|c|}{ Promising targets ${ }^{2}$} \\
\hline CD56 & 117 TMA (TS) + TS & $\begin{array}{c}\text { Average } 96 \% \\
\text { (range } 90-100 \% \text { ) }\end{array}$ & $\begin{array}{c}>50 \% \text { positive cells in } \\
>75 \% \text { of sample }\end{array}$ & N.D. & N.D. & N.D. & [113-117] \\
\hline IGF-1R & $124 \mathrm{~TB}+\mathrm{RM}$ & $63-83 \%$ & N.D. & N.D. & N.D. & Yes & {$[56,118,119]$} \\
\hline VEGF-A & 145 TMA (PR) + PR + RR & $59-70 \%$ & N.D. & N.D. & N.D. & N.D. & {$[120,121]$} \\
\hline B7-H3 & 4 patient-derived xenografts & $100 \%$ & $\begin{array}{l}\text { Average H-score } 108 \\
\quad(\text { range } 49-150)^{3}\end{array}$ & N.D. & N.D. & Yes & {$[60,122]$} \\
\hline TEM1 & 126 TMA (TB) & $31 \%$ & N.D. & N.D. & N.D. & Yes & {$[112,123]$} \\
\hline $\begin{array}{l}\text { Abbrevi } \\
\text { whether } \\
\text { surface. } \\
\text { promisir } \\
\text { were con } \\
\text { formula }\end{array}$ & $\begin{array}{l}\text { s: TMA-tissue microarray; TS- } \\
\text { as a primary tumor or a recurren } \\
\text { le not described in RMS, it was } \\
\text { r FGS if the expression was evalu } \\
\text { red less promising. }{ }^{3} \text {. The H-scor } \\
(\% \text { cells } 1+)+2 \times(\% \text { cells } 2+)+\end{array}$ & $\begin{array}{l}\text { ssue samples (unspecifie } \\
\text { PR-primary resection } 1 \\
\text { nonstrated that CD56, T } \\
\text { d in at least } 20 \text { tissue san } \\
\text { anged from } 0 \text { to } 300 \text { and is } \\
(\% \text { cells } 3+) \text { ]. }\end{array}$ & $\begin{array}{l}\text { whether it was tissue bio } \\
\text { aterial; RR-recurrency re } \\
\text { M1, and B7-H3 internalize } \\
\text { les for a tumor subtype ar } \\
\text { semiquantitative score ob }\end{array}$ & $\begin{array}{l}\text { sy or resection sample); N.D.- } \\
\text { ection material. }{ }^{1} \text {. Endocytosi } \\
d \text { upon binding with an antibc } \\
d \text { more than } 50 \% \text { of the sample } \\
\text { tained by determining the stain }\end{array}$ & $\begin{array}{l}\text { not described; TB-tissue biopsi } \\
\text { f an extracellular molecule upon } \\
\text { y (derivative) in a different tum } \\
\text { stained positive. When targets di } \\
\text { g intensity score (ranging from } 0\end{array}$ & $\begin{array}{l}\text { RM-resection mate } \\
\text { inding to a specific } \mathrm{p} \\
\text { type [56]. }{ }^{2} \text {. Targets } \\
\text { not meet these two re } \\
\text { 3) of each tumor cell }\end{array}$ & $\begin{array}{l}\text { (unspecified } \\
\text { in on the cell } \\
\text { e considered } \\
\text { ements, they } \\
\text { applying the }\end{array}$ \\
\hline
\end{tabular}




\section{Disadvantages of Using Antibodies for Fluorescence-Guided Surgery and Their Alternatives}

Although antibodies bind to their target with high affinity and specificity, the large size of antibodies $(150 \mathrm{kDa})$ is expected to limit tumor penetration and establish a long blood half-life. Therefore, the use of antibodies as targeted tracers for tumor-specific FGS necessitates a turnover time of several days to obtain an optimal tumor-to-background ratio [124]. For patients, this implicates an extra preoperative hospital visit for tracer administration. Apart from the extra costs and logistic planning, this leads to an extra burden for pediatric OS, ES, and RMS patients. Therefore, smaller targeting moiety alternatives such as antibody fragments, peptide conjugates and small molecule conjugates may be advantageous for FGS [33]. Briefly, tracers smaller than $60 \mathrm{kDa}$ are generally cleared via the kidneys instead of via the liver, resulting in faster blood clearance from non-targeted tissues. Consequently, a high tumor-to-background contrast can be attained within hours after the administration of a tumor-specific smaller targeting moiety alternative-based tracer $[26,33,125]$.

As mentioned before, deeper located tumors could still be missed by these tracers $[25,49]$. To this end, hybrid radionuclear/fluorescence imaging combined into a single tracer is attractive. The nuclear component can be of added value for initial intra-operative navigation towards the tumor using a gamma-detecting probe. When the tumor is reached, fluorescence could provide high resolution visual guidance for precise resection [125]. The integration of both modalities onto a tracer can be effectuated in several ways. The conjugation of a fluorophore and chelator for radioactive labeling at different positions of the tracer is one option. Examples include colorectal carcinoma imaging using fluoresceinated monoclonal antibodies against carcinoembryonic antigen which were also labeled with 125I, and the conjugation of IRDye800CW and 111In to Girentuximab for the visualization of clear-cell renal-cell carcinomas [126,127]. Combining the NIR fluorophore and the radiolabel into a single structure is another option [128]. This would be advantageous since this is in most cases a site-specific labeling method which implies that the properties of the tracer cannot vary, creating a predictable tracer with regards to its biodistribution. In addition, this is often the only possibility when working with small peptides or chemical molecules, as multiple conjugation sites may not be available. An example of this technique is the hybrid nuclear and NIR fluorescent PSMA tracer in prostate cancer [129]. However, these single structures are more complex to design, as opposed to the more straightforward separate conjugation of the fluorophore and chelator to an antibody.

\section{Future Perspective and Recommendations for Fluorescence-Guided Surgery in OS, ES, and RMS Patients}

In general, the standard preclinical work preceding the application of FGS consists of the following: target selection, target evaluation, tracer development, in-vitro evaluation, in vivo evaluation with animal experiments, and clinical in-human experiments. Because FGS for pediatric OS, ES, and RMS patients is still in its infancy, this review reveals an overview of promising targets as a basic first step. A follow-up would be to evaluate the expression of these targets with immunohistochemistry in a comparative setting using intra-patient sets of tumor and control tissue. Ideally, fresh surgically resected- or frozen tissue with representative intra- and intertumoral heterogeneity should be used to determine the level and diffusivity of target expression [130,131]. A possible advantage of frozen tissue would be that the antigenicity of its targets may be comparable to those on in-human tumors. The disadvantage is probably the logistics of obtaining these samples in a (large) representative cohort which would involve prospective sampling in a multicenter setting. Therefore, we recommend first evaluating the expression of targets with immunohistochemistry using FFPE samples, given its availability and relatively low cost. Subsequently, the expression of promising targets should be evaluated in fresh surgically resected- or frozen tissue. This enables the systematic, cost-effective, and valid selection of candidate targets for FGS. Then, fluorescent tracers should be developed based on the most favorable target evaluated by immunohistochemistry. Clinically available antibodies conjugated to fluorophores that bind to these targets allow faster and cost-efficient translation to clinics. 
Afterwards, preclinical (mouse) models can be used to show in-vivo efficacy. However, the major disadvantages of genetically altered mice are the absence of human tumor microenvironment and the difficulty of mimicking intertumoral heterogeneity. Therefore, results cannot be directly extrapolated to the clinical setting. Ultimately, the assessment of the additive value of FGS can only be performed in humans.

\section{Conclusions}

We created an overview of the potential of non-targeted and targeted FGS for pediatric OS, ES, and RMS patients. Although ICG has been shown to be safe in pediatric patients, the results of an ongoing clinical trial (scheduled end-date of December 2022) will reveal whether FGS using ICG is accurate for the intra-operative visual identification of pediatric OS, ES, and RMS patients. As FGS using ICG is based on the EPR effect, false negative and false positive signals could occur. Therefore, targeted FGS might be a better alternative. We listed the promising tumor-specific targets for FGS in pediatric OS, ES, and RMS patients. The conjugation of fluorophores to clinically available antibodies that bind to these targets may result in safe and tumor-specific tracers that could improve tumor resection success rates. Evaluating the already clinically tested fluorescent-labeled antibody BevacizumabIRDye800CW in pediatric OS and RMS patients is a relatively straightforward option because this has already shown promising results in adult soft tissue sarcomas. However, the development of a fluorescent-labeled IGF-1R antibody would be ideal because this seems to be the only promising target for pediatric OS, ES, and RMS simultaneously. Due to disadvantages of antibody-based tracers, smaller targeting moiety alternatives for tracer development should be investigated. In addition, surgical navigation with the use of hybrid radionuclear/fluorescence tracers could be investigated to detect deeper located and hidden tumors. In conclusion, FGS has the potential to optimize OS, ES, and RMS treatment, but more research remains to be done before this promising technique can be implemented for OS, ES, and RMS patients.

Supplementary Materials: The following are available online at https:/ / www.mdpi.com/article / 10.3390/biomedicines9101388/s1, Table S1: Published/completed trials with clinically available antibodies for osteosarcoma-, rhabdomyosarcoma-, and Ewing sarcoma patients; Table S2: Ongoing/unpublished trials with clinically available antibodies for osteosarcoma-, rhabdomyosarcoma-, and Ewing sarcoma patients.

Author Contributions: Conceptualization, Z.R., B.J. and N.S.; writing-original draft preparation, Z.R., B.J. and N.S.; writing—review and editing, Z.R., B.J., N.S., H.G., C.F.M.S., A.L.V., F.W.B.v.L., A.F.W.v.d.S. and M.A.J.v.d.S.; supervision, H.G., A.F.W.v.d.S. and M.A.J.v.d.S. All authors have read and agreed to the published version of the manuscript.

Funding: C.F.M.S. was supported by the European Union's Horizon 2020 research and innovation programme under the Marie Sklodowska Curie grant agreement No. 734684 (CHARMED), 872391 (CONCRETE), and PRISAR2 (872860).

Institutional Review Board Statement: Not applicable.

Informed Consent Statement: Not applicable.

Data Availability Statement: Not applicable.

Conflicts of Interest: Not applicable.

\section{Appendix A}

PubMed search strategy for clinical trials investigating antibodies in OS, RMS, or ES:

("Antibodies"[Mesh] OR "antibodies"[tw] OR "antibody"[tw] OR "Immunoglobulins"[Mesh] OR "Immunoglobulins"[tw] OR "Immunoglobulin"[tw] OR (("targeted"[All Fields] OR "target" "therapy" $[\mathrm{tw}] \mathrm{OR}$ "therap $\left.\left.{ }^{* \prime}[\mathrm{tw}]\right)\right)$ )

AND 
("Rhabdomyosarcoma"[MeSH] OR “Rhabdomyosarcoma”[tw] OR “Rhabdomyosar*”[tw] OR "sarcoma, Ewing" [MeSH] OR “Ewing sarcoma" [tw] OR “Ewing's Sarcoma" [tw] OR "Ewings Sarcoma" $[\mathrm{tw}]$ OR “Ewing's Tumor" $[\mathrm{tw}]$ OR "Ewings Tumor" $[\mathrm{tw}]$ OR "Ewing tumor" $[\mathrm{tw}] \mathrm{OR}$ "Osteosarcoma" $[\mathrm{MeSH}]$ OR “Osteosarcoma" [tw] OR “Osteosarc”" $[\mathrm{tw}] \mathrm{OR}$ “Osteogenic sarc*"[tw])

AND

(“Child" [MeSH] OR "child"[tw] OR "child" [tw] OR "infant"[MeSH] OR "infant"[tw] OR "infant*" $[\mathrm{tw}]$ OR "pediatrics" $[\mathrm{MeSH}]$ OR "pediatric" $[\mathrm{tw}] \mathrm{OR}$ "pediatric*" $[\mathrm{tw}]$ OR "young adult" $[\mathrm{tw}]$ OR "young adult*"[tw] OR "young" $[\mathrm{tw}]$ OR "youth" $[\mathrm{tw}]$ OR "youth*"[tw] OR "adolescent" $[\mathrm{MeSH}] \mathrm{OR}$ "adolescent" $[\mathrm{tw}] \mathrm{OR}$ "adolescent" ${ }^{*}$ [tw] OR "adolescence" $[\mathrm{tw}] \mathrm{OR}$ “adolescen*”[tw] OR “teen" [tw] OR “teen*"[tw])

\section{References}

1. Bompas, E.; Martin, V.; Meniai, F.; Toulmonde, M.; Marec-Berard, P.; Claude, L.; Ducimetiere, F.; Chargari, C.; Minard-Colin, V.; Corradini, N.; et al. Management of sarcomas in children, adolescents and adults: Interactions in two different age groups under the umbrellas of GSF-GETO and SFCE, with the support of the NETSARC+ network. Bull. Cancer 2021, 108, 163-176. [CrossRef]

2. Hernandez Tejada, F.N.; Zamudio, A.; Marques-Piubelli, M.L.; Cuglievan, B.; Harrison, D. Advances in the Management of Pediatric Sarcomas. Curr. Oncol. Rep. 2020, 23, 3. [CrossRef] [PubMed]

3. Stiller, C.A.; Trama, A.; Serraino, D.; Rossi, S.; Navarro, C.; Chirlaque, M.D.; Casali, P.G. Descriptive epidemiology of sarcomas in Europe: Report from the RARECARE project. Eur. J. Cancer 2013, 49, 684-695. [CrossRef] [PubMed]

4. Ritter, J.; Bielack, S.S. Osteosarcoma. Ann. Oncol. 2010, 21 (Suppl. 7), vii320-vii325. [CrossRef] [PubMed]

5. Esiashvili, N.; Goodman, M.; Marcus, R.B., Jr. Changes in incidence and survival of Ewing sarcoma patients over the past 3 decades: Surveillance Epidemiology and End Results data. J. Pediatr. Hematol. Oncol. 2008, 30, 425-430. [CrossRef]

6. Chen, S.; Rudzinski, E.R.; Arnold, M.A. Challenges in the Diagnosis of Pediatric Spindle Cell/Sclerosing Rhabdomyosarcoma. Surg. Pathol. Clin. 2020, 13, 729-738. [CrossRef]

7. Bailey, K.; Cost, C.; Davis, I.; Glade-Bender, J.; Grohar, P.; Houghton, P.; Isakoff, M.; Stewart, E.; Laack, N.; Yustein, J.; et al. Emerging novel agents for patients with advanced Ewing sarcoma: A report from the Children's Oncology Group (COG) New Agents for Ewing Sarcoma Task Force. F1000Research 2019, 8, 493. [CrossRef]

8. Bernthal, N.M.; Federman, N.; Eilber, F.R.; Nelson, S.D.; Eckardt, J.J.; Eilber, F.C.; Tap, W.D. Long-term results (>25 years) of a randomized, prospective clinical trial evaluating chemotherapy in patients with high-grade, operable osteosarcoma. Cancer 2012, 118, 5888-5893. [CrossRef]

9. Crist, W.M.; Anderson, J.R.; Meza, J.L.; Fryer, C.; Raney, R.B.; Ruymann, F.B.; Breneman, J.; Qualman, S.J.; Wiener, E.; Wharam, M.; et al. Intergroup rhabdomyosarcoma study-IV: Results for patients with nonmetastatic disease. J. Clin. Oncol. Off. J. Am. Soc. Clin. Oncol. 2001, 19, 3091-3102. [CrossRef] [PubMed]

10. Goorin, A.M.; Schwartzentruber, D.J.; Devidas, M.; Gebhardt, M.C.; Ayala, A.G.; Harris, M.B.; Helman, L.J.; Grier, H.E.; Link, M.P. Presurgical chemotherapy compared with immediate surgery and adjuvant chemotherapy for nonmetastatic osteosarcoma: Pediatric Oncology Group Study POG-8651. J. Clin. Oncol. Off. J. Am. Soc. Clin. Oncol. 2003, 21, 1574-1580. [CrossRef] [PubMed]

11. Williams, R.F.; Fernandez-Pineda, I.; Gosain, A. Pediatric Sarcomas. Surg. Clin. N. Am. 2016, 96, 1107-1125. [CrossRef]

12. He, F.; Zhang, W.; Shen, Y.; Yu, P.; Bao, Q.; Wen, J.; Hu, C.; Qiu, S. Effects of resection margins on local recurrence of osteosarcoma in extremity and pelvis: Systematic review and meta-analysis. Int. J. Surg. 2016, 36, 283-292. [CrossRef] [PubMed]

13. Loh, A.H.; Wu, H.; Bahrami, A.; Navid, F.; McCarville, M.B.; Wang, C.; Wu, J.; Bishop, M.W.; Daw, N.C.; Neel, M.D.; et al. Influence of bony resection margins and surgicopathological factors on outcomes in limb-sparing surgery for extremity osteosarcoma. Pediatr. Blood Cancer 2015, 62, 246-251. [CrossRef]

14. Abed, R.; Grimer, R. Surgical modalities in the treatment of bone sarcoma in children. Cancer Treat Rev. 2010, 36, 342-347. [CrossRef]

15. Donaldson, S.S. Ewing sarcoma: Radiation dose and target volume. Pediatr. Blood Cancer 2004, 42, 471-476. [CrossRef]

16. Bacci, G.; Longhi, A.; Briccoli, A.; Bertoni, F.; Versari, M.; Picci, P. The role of surgical margins in treatment of Ewing's sarcoma family tumors: Experience of a single institution with 512 patients treated with adjuvant and neoadjuvant chemotherapy. Int. J. Radiat. Oncol. Biol. Phys. 2006, 65, 766-772. [CrossRef]

17. Foulon, S.; Brennan, B.; Gaspar, N.; Dirksen, U.; Jeys, L.; Cassoni, A.; Claude, L.; Seddon, B.; Marec-Berard, P.; Whelan, J.; et al. Can postoperative radiotherapy be omitted in localised standard-risk Ewing sarcoma? An observational study of the Euro-E.W.I.N.G group. Eur. J. Cancer 2016, 61, 128-136. [CrossRef]

18. Hawkins, W.G.; Hoos, A.; Antonescu, C.R.; Urist, M.J.; Leung, D.H.; Gold, J.S.; Woodruff, J.M.; Lewis, J.J.; Brennan, M.F. Clinicopathologic analysis of patients with adult rhabdomyosarcoma. Cancer 2001, 91, 794-803. [CrossRef]

19. Ozaki, T.; Hillmann, A.; Hoffmann, C.; Rübe, C.; Blasius, S.; Dunst, J.; Jürgens, H.; Winkelmann, W. Significance of surgical margin on the prognosis of patients with Ewing's sarcoma. A report from the Cooperative Ewing's Sarcoma Study. Cancer 1996, 78, 892-900. [CrossRef] 
20. Seitz, G.; Dantonello, T.M.; Int-Veen, C.; Blumenstock, G.; Godzinski, J.; Klingebiel, T.; Schuck, A.; Leuschner, I.; Koscielniak, E.; Fuchs, J. Treatment efficiency, outcome and surgical treatment problems in patients suffering from localized embryonal bladder/prostate rhabdomyosarcoma: A report from the Cooperative Soft Tissue Sarcoma trial CWS-96. Pediatr. Blood Cancer 2011, 56, 718-724. [CrossRef] [PubMed]

21. Physician Data Query Pediatric Treatment Editorial Board. Late Effects of Treatment for Childhood Cancer (PDQ $\left.{ }^{\circledR}\right)$ : Health Professional Version. In PDQ Cancer Information Summaries; National Cancer Institute (US): Bethesda, MD, USA, 2002.

22. Paulino, A.C.; Simon, J.H.; Zhen, W.; Wen, B.C. Long-term effects in children treated with radiotherapy for head and neck rhabdomyosarcoma. Int. J. Radiat. Oncol. Biol. Phys. 2000, 48, 1489-1495. [CrossRef]

23. Egloff-Juras, C.; Bezdetnaya, L.; Dolivet, G.; Lassalle, H.P. NIR fluorescence-guided tumor surgery: New strategies for the use of indocyanine green. Int. J. Nanomed. 2019, 14, 7823-7838. [CrossRef]

24. Rijs, Z.; Shifai, A.N.; Bosma, S.E.; Kuppen, P.J.K.; Vahrmeijer, A.L.; Keereweer, S.; Bovée, J.; van de Sande, M.A.J.; Sier, C.F.M.; van Driel, P. Candidate Biomarkers for Specific Intraoperative Near-Infrared Imaging of Soft Tissue Sarcomas: A Systematic Review. Cancers 2021, 13, 557. [CrossRef] [PubMed]

25. Cao, J.; Zhu, B.; Zheng, K.; He, S.; Meng, L.; Song, J.; Yang, H. Recent Progress in NIR-II Contrast Agent for Biological Imaging. Front. Bioeng. Biotechnol. 2019, 7, 487. [CrossRef]

26. Hernot, S.; van Manen, L.; Debie, P.; Mieog, J.S.D.; Vahrmeijer, A.L. Latest developments in molecular tracers for fluorescence image-guided cancer surgery. Lancet Oncol. 2019, 20, e354-e367. [CrossRef]

27. Vahrmeijer, A.L.; Hutteman, M.; van der Vorst, J.R.; van de Velde, C.J.; Frangioni, J.V. Image-guided cancer surgery using near-infrared fluorescence. Nat. Rev. Clin. Oncol. 2013, 10, 507-518. [CrossRef] [PubMed]

28. Schaafsma, B.E.; Mieog, J.S.; Hutteman, M.; van der Vorst, J.R.; Kuppen, P.J.; Löwik, C.W.; Frangioni, J.V.; van de Velde, C.J.; Vahrmeijer, A.L. The clinical use of indocyanine green as a near-infrared fluorescent contrast agent for image-guided oncologic surgery. J. Surg. Oncol. 2011, 104, 323-332. [CrossRef]

29. Barth, C.W.; Gibbs, S.L. Fluorescence Image-Guided Surgery-A Perspective on Contrast Agent Development. Proc. SPIE Int. Soc. Opt. Eng. 2020, 11222. [CrossRef]

30. Keereweer, S.; Kerrebijn, J.D.; van Driel, P.B.; Xie, B.; Kaijzel, E.L.; Snoeks, T.J.; Que, I.; Hutteman, M.; van der Vorst, J.R.; Mieog, J.S.; et al. Optical image-guided surgery-Where do we stand? Mol. Imaging Biol. 2011, 13, 199-207. [CrossRef] [PubMed]

31. Benson, R.C.; Kues, H.A. Fluorescence properties of indocyanine green as related to angiography. Phys. Med. Biol. 1978, 23, 159-163. [CrossRef]

32. Debie, P.; Hernot, S. Emerging Fluorescent Molecular Tracers to Guide Intra-Operative Surgical Decision-Making. Front. Pharm. 2019, 10, 510. [CrossRef]

33. Jiao, J.; Zhang, J.; Yang, F.; Song, W.; Han, D.; Wen, W.; Qin, W. Quicker, deeper and stronger imaging: A review of tumor-targeted, near-infrared fluorescent dyes for fluorescence guided surgery in the preclinical and clinical stages. Eur. J. Pharm. Biopharm. 2020, 152, 123-143. [CrossRef]

34. Baljer, B.C.; Kolhe, S.; Chan, C.D.; Nicoli, F.; Ghanbasha, A.; Brookes, M.J.; Gamie, Z.; Ghosh, K.M.; Beckingsale, T.B.; Saleh, D.B.; et al. Advances in image enhancement for sarcoma surgery. Cancer Lett. 2020, 483, 1-11. [CrossRef]

35. Verdye. Samenvatting van de productenkenmerken. UK/H/0654/01. Available online: https://www.geneesmiddeleninformatiebank. $\mathrm{nl} / \mathrm{smpc} / \mathrm{h} 31052 \_$smpc.pdf (accessed on 14 April 2021).

36. Bunschoten, A.; Buckle, T.; Kuil, J.; Luker, G.D.; Luker, K.E.; Nieweg, O.E.; van Leeuwen, F.W. Targeted non-covalent selfassembled nanoparticles based on human serum albumin. Biomaterials 2012, 33, 867-875. [CrossRef]

37. Matsumura, Y.; Maeda, H. A new concept for macromolecular therapeutics in cancer chemotherapy: Mechanism of tumoritropic accumulation of proteins and the antitumor agent smancs. Cancer Res. 1986, 46, 6387-6392. [PubMed]

38. Esposito, C.; Settimi, A.; Del Conte, F.; Cerulo, M.; Coppola, V.; Farina, A.; Crocetto, F.; Ricciardi, E.; Esposito, G.; Escolino, M. Image-Guided Pediatric Surgery Using Indocyanine Green (ICG) Fluorescence in Laparoscopic and Robotic Surgery. Front. Pediatr. 2020, 8, 314. [CrossRef] [PubMed]

39. Goldstein, S.D.; Heaton, T.E.; Bondoc, A.; Dasgupta, R.; Abdelhafeez, A.; Davidoff, A.M.; Lautz, T.B. Evolving applications of fluorescence guided surgery in pediatric surgical oncology: A practical guide for surgeons. J. Pediatr. Surg. 2021, 56, 215-223. [CrossRef] [PubMed]

40. Nicoli, F.; Saleh, D.B.; Baljer, B.; Chan, C.D.; Beckingsale, T.; Ghosh, K.M.; Ragbir, M.; Rankin, K.S. Intraoperative Near-infrared Fluorescence (NIR) Imaging With Indocyanine Green (ICG) Can Identify Bone and Soft Tissue Sarcomas Which May Provide Guidance for Oncological Resection. Ann. Surg. 2021, 273, e63-e68. [CrossRef] [PubMed]

41. Croteau, N.J.; Heaton, T.E. Pulmonary Metastasectomy in Pediatric Solid Tumors. Children 2019, 6, 6. [CrossRef]

42. Predina, J.D.; Newton, A.D.; Corbett, C.; Shin, M.; Sulfyok, L.F.; Okusanya, O.T.; Delikatny, E.J.; Nie, S.; Gaughan, C.; Jarrar, D.; et al. Near-infrared intraoperative imaging for minimally invasive pulmonary metastasectomy for sarcomas. J. Thorac. Cardiovasc. Surg. 2019, 157, 2061-2069. [CrossRef]

43. Keating, J.; Newton, A.; Venegas, O.; Nims, S.; Zeh, R.; Predina, J.; Deshpande, C.; Kucharczuk, J.; Nie, S.; Delikatny, E.J.; et al. Near-Infrared Intraoperative Molecular Imaging Can Locate Metastases to the Lung. Ann. Thorac. Surg. 2017, 103, 390-398. [CrossRef]

44. Okusanya, O.T.; Holt, D.; Heitjan, D.; Deshpande, C.; Venegas, O.; Jiang, J.; Judy, R.; DeJesus, E.; Madajewski, B.; Oh, K.; et al. Intraoperative near-infrared imaging can identify pulmonary nodules. Ann. Thorac. Surg. 2014, 98, 1223-1230. [CrossRef] 
45. Chen, Y.; Cruz, F.D.; Sandhu, R.; Kung, A.L.; Mundi, P.; Deasy, J.O.; Tannenbaum, A. Pediatric Sarcoma Data Forms a Unique Cluster Measured via the Earth Mover's Distance. Sci. Rep. 2017, 7, 7035. [CrossRef]

46. Govaert, G.A.; Oostenbroek, R.J.; Plaisier, P.W. Prolonged skin staining after intradermal use of patent blue in sentinel lymph node biopsy for breast cancer. Eur. J. Surg. Oncol. 2005, 31, 373-375. [CrossRef]

47. Nunez, A.; Jones, V.; Schulz-Costello, K.; Schmolze, D. Accuracy of gross intraoperative margin assessment for breast cancer: Experience since the SSO-ASTRO margin consensus guidelines. Sci. Rep. 2020, 10, 17344. [CrossRef] [PubMed]

48. Kaneko, J.; Ishizawa, T.; Masuda, K.; Kawaguchi, Y.; Aoki, T.; Sakamoto, Y.; Hasegawa, K.; Sugawara, Y.; Kokudo, N. Indocyanine green reinjection technique for use in fluorescent angiography concomitant with cholangiography during laparoscopic cholecystectomy. Surg. Laparosc. Endosc. Percutan. Tech. 2012, 22, 341-344. [CrossRef] [PubMed]

49. Shao, W.; Chen, G.; Kuzmin, A.; Kutscher, H.L.; Pliss, A.; Ohulchanskyy, T.Y.; Prasad, P.N. Tunable Narrow Band Emissions from Dye-Sensitized Core/Shell/Shell Nanocrystals in the Second Near-Infrared Biological Window. J. Am. Chem. Soc. 2016, 138, 16192-16195. [CrossRef] [PubMed]

50. Makek, M.; Grant, J.W. Epithelial-myoepithelial carcinoma of the parotid gland associated with a primary carcinoma of the lung. Int. J. Oral. Maxillofac. Surg. 1988, 17, 134-137. [CrossRef]

51. Holt, D.; Okusanya, O.; Judy, R.; Venegas, O.; Jiang, J.; DeJesus, E.; Eruslanov, E.; Quatromoni, J.; Bhojnagarwala, P.; Deshpande, C.; et al. Intraoperative near-infrared imaging can distinguish cancer from normal tissue but not inflammation. $P L o S$ ONE 2014, 9, e103342. [CrossRef]

52. Tummers, Q.R.; Hoogstins, C.E.; Peters, A.A.; de Kroon, C.D.; Trimbos, J.B.; van de Velde, C.J.; Frangioni, J.V.; Vahrmeijer, A.L.; Gaarenstroom, K.N. The Value of Intraoperative Near-Infrared Fluorescence Imaging Based on Enhanced Permeability and Retention of Indocyanine Green: Feasibility and False-Positives in Ovarian Cancer. PLoS ONE 2015, 10, e0129766. [CrossRef]

53. Bosma, S.E.; van Driel, P.B.; Hogendoorn, P.C.; Dijkstra, P.S.; Sier, C.F. Introducing fluorescence guided surgery into orthopedic oncology: A systematic review of candidate protein targets for Ewing sarcoma. J. Surg. Oncol. 2018, 118, 906-914. [CrossRef] [PubMed]

54. Russell-Goldman, E.; Hornick, J.L.; Qian, X.; Jo, V.Y. NKX2.2 immunohistochemistry in the distinction of Ewing sarcoma from cytomorphologic mimics: Diagnostic utility and pitfalls. Cancer Cytopathol. 2018, 126, 942-949. [CrossRef] [PubMed]

55. Gao, R.W.; Teraphongphom, N.; de Boer, E.; van den Berg, N.S.; Divi, V.; Kaplan, M.J.; Oberhelman, N.J.; Hong, S.S.; Capes, E.; Colevas, A.D.; et al. Safety of panitumumab-IRDye800CW and cetuximab-IRDye800CW for fluorescence-guided surgical navigation in head and neck cancers. Theranostics 2018, 8, 2488-2495. [CrossRef]

56. Garofalo, C.; Mancarella, C.; Grilli, A.; Manara, M.C.; Astolfi, A.; Marino, M.T.; Conte, A.; Sigismund, S.; Carè, A.; Belfiore, A.; et al. Identification of common and distinctive mechanisms of resistance to different anti-IGF-IR agents in Ewing's sarcoma. Mol. Endocrinol. 2012, 26, 1603-1616. [CrossRef] [PubMed]

57. Guo, Z.; Liu, Y.; Zhou, H.; Zheng, K.; Wang, D.; Jia, M.; Xu, P.; Ma, K.; Cui, C.; Wang, L. CD47-targeted bismuth selenide nanoparticles actualize improved photothermal therapy by increasing macrophage phagocytosis of cancer cells. Colloids Surf. B Biointerfaces 2019, 184, 110546. [CrossRef] [PubMed]

58. Leconet, W.; Larbouret, C.; Chardès, T.; Thomas, G.; Neiveyans, M.; Busson, M.; Jarlier, M.; Radosevic-Robin, N.; Pugnière, M.; Bernex, F.; et al. Preclinical validation of AXL receptor as a target for antibody-based pancreatic cancer immunotherapy. Oncogene 2014, 33, 5405-5414. [CrossRef]

59. Wang, C.H.; Huang, Y.J.; Chang, C.W.; Hsu, W.M.; Peng, C.A. In vitro photothermal destruction of neuroblastoma cells using carbon nanotubes conjugated with GD2 monoclonal antibody. Nanotechnology 2009, 20, 315101. [CrossRef]

60. Wilson, K.E.; Bachawal, S.V.; Abou-Elkacem, L.; Jensen, K.; Machtaler, S.; Tian, L.; Willmann, J.K. Spectroscopic Photoacoustic Molecular Imaging of Breast Cancer using a B7-H3-targeted ICG Contrast Agent. Theranostics 2017, 7, 1463-1476. [CrossRef]

61. Bauer, M.; Macdonald, J.; Henri, J.; Duan, W.; Shigdar, S. The Application of Aptamers for Immunohistochemistry. Nucleic Acid Ther. 2016, 26, 120-126. [CrossRef]

62. Hira, V.V.V.; de Jong, A.L.; Ferro, K.; Khurshed, M.; Molenaar, R.J.; Van Noorden, C.J.F. Comparison of different methodologies and cryostat versus paraffin sections for chromogenic immunohistochemistry. Acta Histochem. 2019, 121, 125-134. [CrossRef]

63. Kersting, C.; Packeisen, J.; Leidinger, B.; Brandt, B.; von Wasielewski, R.; Winkelmann, W.; van Diest, P.J.; Gosheger, G.; Buerger, H. Pitfalls in immunohistochemical assessment of EGFR expression in soft tissue sarcomas. J. Clin. Pathol. 2006, 59, 585-590. [CrossRef]

64. Stumptner, C.; Pabst, D.; Loibner, M.; Viertler, C.; Zatloukal, K. The impact of crosslinking and non-crosslinking fixatives on antigen retrieval and immunohistochemistry. New Biotechnol. 2019, 52, 69-83. [CrossRef] [PubMed]

65. Chen, S.; Guenther, L.M.; Aronhalt, A.; Cardillo, L.; Janeway, K.A.; Church, A.J. PD-1 and PD-L1 Expression in Osteosarcoma: Which Specimen to Evaluate? J. Pediatr. Hematol. Oncol. 2020, 42, 482-487. [CrossRef] [PubMed]

66. Forest, F.; Cote, G.; Laville, D.; Da Cruz, V.; Dal Col, P.; Camy, F.; Mobarki, M.; Clemenson, A.; Yvorel, V.; Péoc’h, M. Impact of delayed fixation and decalcification on PD-L1 expression: A comparison of two clones. Virchows Arch. Int. J. Pathol. 2019, 475, 693-699. [CrossRef]

67. Boi, G.; Scalia, C.R.; Gendusa, R.; Ronchi, S.; Cattoretti, G. Disaccharides Protect Antigens from Drying-Induced Damage in Routinely Processed Tissue Sections. J. Histochem. Cytochem. Off. J. Histochem. Soc. 2016, 64, 18-31. [CrossRef] 
68. Fujihara, R.; Chiba, Y.; Nakagawa, T.; Murakami, R.; Matsumoto, K.; Kawauchi, M.; Fujii, T.; Shimono, R.; Yamamoto, T.; Ueno, M. Histomorphometry of ectopic mineralization using undecalcified frozen bone sections. Microsc. Res. Tech. 2018, 81, 1318-1324. [CrossRef]

69. Mathieson, W.; Marcon, N.; Antunes, L.; Ashford, D.A.; Betsou, F.; Frasquilho, S.G.; Kofanova, O.A.; McKay, S.C.; Pericleous, S.; Smith, C.; et al. A Critical Evaluation of the PAXgene Tissue Fixation System: Morphology, Immunohistochemistry, Molecular Biology, and Proteomics. Am. J. Clin. Pathol. 2016, 146, 25-40. [CrossRef] [PubMed]

70. Ralton, L.D.; Murray, G.I. The use of formalin fixed wax embedded tissue for proteomic analysis. J. Clin. Pathol. 2011, 64, 297-302. [CrossRef]

71. Rodig, S.J. Preparing Frozen Tissue Sections for Staining. Cold Spring Harb. Protoc. 2021, 2021. [CrossRef]

72. Coats, S.; Williams, M.; Kebble, B.; Dixit, R.; Tseng, L.; Yao, N.S.; Tice, D.A.; Soria, J.C. Antibody-Drug Conjugates: Future Directions in Clinical and Translational Strategies to Improve the Therapeutic Index. Clin. Cancer Res. Off. J. Am. Assoc. Cancer Res. 2019, 25, 5441-5448. [CrossRef]

73. De Jongh, S.J.; Tjalma, J.J.J.; Koller, M.; Linssen, M.D.; Vonk, J.; Dobosz, M.; Jorritsma-Smit, A.; Kleibeuker, J.H.; Hospers, G.A.P.; Havenga, K.; et al. Back-Table Fluorescence-Guided Imaging for Circumferential Resection Margin Evaluation Using Bevacizumab-800CW in Patients with Locally Advanced Rectal Cancer. J. Nucl. Med. 2020, 61, 655-661. [CrossRef]

74. Harlaar, N.J.; Koller, M.; de Jongh, S.J.; van Leeuwen, B.L.; Hemmer, P.H.; Kruijff, S.; van Ginkel, R.J.; Been, L.B.; de Jong, J.S.; Kats-Ugurlu, G.; et al. Molecular fluorescence-guided surgery of peritoneal carcinomatosis of colorectal origin: A single-centre feasibility study. Lancet Gastroenterol. Hepatol. 2016, 1, 283-290. [CrossRef]

75. Korb, M.L.; Hartman, Y.E.; Kovar, J.; Zinn, K.R.; Bland, K.I.; Rosenthal, E.L. Use of monoclonal antibody-IRDye800CW bioconjugates in the resection of breast cancer. J. Surg. Res. 2014, 188, 119-128. [CrossRef] [PubMed]

76. Lamberts, L.E.; Koch, M.; de Jong, J.S.; Adams, A.L.L.; Glatz, J.; Kranendonk, M.E.G.; Terwisscha van Scheltinga, A.G.T.; Jansen, L.; de Vries, J.; Lub-de Hooge, M.N.; et al. Tumor-Specific Uptake of Fluorescent Bevacizumab-IRDye800CW Microdosing in Patients with Primary Breast Cancer: A Phase I Feasibility Study. Clin. Cancer Res. Off. J. Am. Assoc. Cancer Res. 2017, 23, 2730-2741. [CrossRef] [PubMed]

77. Steinkamp, P.J.; Pranger, B.K.; Li, M.F.; Linssen, M.D.; Voskuil, F.J.; Been, L.B.; van Leeuwen, B.L.; Suurmeijer, A.J.H.; Nagengast, W.B.; Kruijff, S.; et al. Fluorescence-Guided Visualization of Soft-Tissue Sarcomas by Targeting Vascular Endothelial Growth Factor A: A Phase 1 Single-Center Clinical Trial. J. Nucl. Med. 2021, 62, 342-347. [CrossRef]

78. Zhang, Y.; Tang, Y.J.; Man, Y.; Pan, F.; Li, Z.H.; Jia, L.S. Knockdown of AXL receptor tyrosine kinase in osteosarcoma cells leads to decreased proliferation and increased apoptosis. Int. J. Immunopathol. Pharmacol. 2013, 26, 179-188. [CrossRef] [PubMed]

79. Rettew, A.N.; Young, E.D.; Lev, D.C.; Kleinerman, E.S.; Abdul-Karim, F.W.; Getty, P.J.; Greenfield, E.M. Multiple receptor tyrosine kinases promote the in vitro phenotype of metastatic human osteosarcoma cell lines. Oncogenesis 2012, 1, e34. [CrossRef] [PubMed]

80. Wang, L.; Zhang, Q.; Chen, W.; Shan, B.; Ding, Y.; Zhang, G.; Cao, N.; Liu, L.; Zhang, Y. B7-H3 is overexpressed in patients suffering osteosarcoma and associated with tumor aggressiveness and metastasis. PLoS ONE 2013, 8, e70689. [CrossRef]

81. Xu, J.F.; Pan, X.H.; Zhang, S.J.; Zhao, C.; Qiu, B.S.; Gu, H.F.; Hong, J.F.; Cao, L.; Chen, Y.; Xia, B.; et al. CD47 blockade inhibits tumor progression human osteosarcoma in xenograft models. Oncotarget 2015, 6, 23662-23670. [CrossRef]

82. Poon, V.I.; Roth, M.; Piperdi, S.; Geller, D.; Gill, J.; Rudzinski, E.R.; Hawkins, D.S.; Gorlick, R. Ganglioside GD2 expression is maintained upon recurrence in patients with osteosarcoma. Clin. Sarcoma Res. 2015, 5, 4. [CrossRef]

83. Roth, M.; Linkowski, M.; Tarim, J.; Piperdi, S.; Sowers, R.; Geller, D.; Gill, J.; Gorlick, R. Ganglioside GD2 as a therapeutic target for antibody-mediated therapy in patients with osteosarcoma. Cancer 2014, 120, 548-554. [CrossRef]

84. Roth, M.; Barris, D.M.; Piperdi, S.; Kuo, V.; Everts, S.; Geller, D.; Houghton, P.; Kolb, E.A.; Hawthorne, T.; Gill, J.; et al. Targeting Glycoprotein NMB With Antibody-Drug Conjugate, Glembatumumab Vedotin, for the Treatment of Osteosarcoma. Pediatr. Blood Cancer 2016, 63, 32-38. [CrossRef]

85. Wang, Y.H.; Han, X.D.; Qiu, Y.; Xiong, J.; Yu, Y.; Wang, B.; Zhu, Z.Z.; Qian, B.P.; Chen, Y.X.; Wang, S.F.; et al. Increased expression of insulin-like growth factor-1 receptor is correlated with tumor metastasis and prognosis in patients with osteosarcoma. J. Surg. Oncol. 2012, 105, 235-243. [CrossRef] [PubMed]

86. Aznab, M.; Khajevand Ahmady, M.; Jamshidi, K.; Madani, S.H.; Khazaei, S.; Shoushtaryzadeh, T.; Bagheri, A. Investigating the Relationship between of Vascular Endothelial Growth Factor and HER-2neu in IHC Staining with Metastasis and Mortality in Patients with Osteosarcoma. Asian Pac. J. Cancer Prev. APJCP 2020, 21, 3005-3009. [CrossRef] [PubMed]

87. Lin, F.; Zheng, S.E.; Shen, Z.; Tang, L.N.; Chen, P.; Sun, Y.J.; Zhao, H.; Yao, Y. Relationships between levels of CXCR4 and VEGF and blood-borne metastasis and survival in patients with osteosarcoma. Med. Oncol. 2011, 28, 649-653. [CrossRef] [PubMed]

88. Lammli, J.; Fan, M.; Rosenthal, H.G.; Patni, M.; Rinehart, E.; Vergara, G.; Ablah, E.; Wooley, P.H.; Lucas, G.; Yang, S.Y. Expression of Vascular Endothelial Growth Factor correlates with the advance of clinical osteosarcoma. Int. Orthop. 2012, 36, $2307-2313$. [CrossRef] [PubMed]

89. Rossi, B.; Schinzari, G.; Maccauro, G.; Scaramuzzo, L.; Signorelli, D.; Rosa, M.A.; Fabbriciani, C.; Carlo, B. Neoadjuvant multidrug chemotherapy including high-dose methotrexate modifies VEGF expression in osteosarcoma: An immunohistochemical analysis. BMC Musculoskelet. Disord. 2010, 11, 34. [CrossRef]

90. Bajpai, J.; Sharma, M.; Sreenivas, V.; Kumar, R.; Gamnagatti, S.; Khan, S.A.; Rastogi, S.; Malhotra, A.; Bakhshi, S. VEGF expression as a prognostic marker in osteosarcoma. Pediatr. Blood Cancer 2009, 53, 1035-1039. [CrossRef] 
91. Charity, R.M.; Foukas, A.F.; Deshmukh, N.S.; Grimer, R.J. Vascular endothelial growth factor expression in osteosarcoma. Clin. Orthop. Relat. Res. 2006, 448, 193-198. [CrossRef]

92. Ek, E.T.; Ojaimi, J.; Kitagawa, Y.; Choong, P.F. Does the degree of intratumoural microvessel density and VEGF expression have prognostic significance in osteosarcoma? Oncol. Rep. 2006, 16, 17-23. [CrossRef]

93. Kaya, M.; Wada, T.; Akatsuka, T.; Kawaguchi, S.; Nagoya, S.; Shindoh, M.; Higashino, F.; Mezawa, F.; Okada, F.; Ishii, S. Vascular endothelial growth factor expression in untreated osteosarcoma is predictive of pulmonary metastasis and poor prognosis. Clin. Cancer Res. Off. J. Am. Assoc. Cancer Res. 2000, 6, 572-577.

94. Boulytcheva, I.V.; Soloviev, Y.N.; Kushlinskii, N.E.; Mahson, A.N. Expression of molecular markers in the tumor and survival prognosis in osteosarcoma. Bull. Exp. Biol. Med. 2010, 150, 237-242. [CrossRef] [PubMed]

95. Becker, R.G.; Galia, C.R.; Morini, S.; Viana, C.R. Immunohistochemical expression of vegf and her-2 proteins in osteosarcoma biopsies. Acta Ortop. Bras. 2013, 21, 233-238. [CrossRef] [PubMed]

96. Yang, J.; Zhao, L.; Tian, W.; Liao, Z.; Zheng, H.; Wang, G.; Chen, K. Correlation of WWOX, RUNX2 and VEGFA protein expression in human osteosarcoma. BMC Med. Genom. 2013, 6, 56. [CrossRef]

97. Abdeen, A.; Chou, A.J.; Healey, J.H.; Khanna, C.; Osborne, T.S.; Hewitt, S.M.; Kim, M.; Wang, D.; Moody, K.; Gorlick, R. Correlation between clinical outcome and growth factor pathway expression in osteogenic sarcoma. Cancer 2009, 115, 5243-5250. [CrossRef]

98. Qu, Y.; Xu, J.; Jiang, T.; Zhao, H.; Gao, Y.; Zheng, C.; Shi, X. Difference in pre- and postchemotherapy vascular endothelial growth factor levels as a prognostic indicator in osteosarcoma. J. Int. Med. Res. 2011, 39, 1474-1482. [CrossRef] [PubMed]

99. Zhang, Q.; Liu, F.; Wang, B.; Li, Z.; Zhou, D.; Yang, Q.; Dong, J.; Li, J. HER-2 expression in biopsy and surgical specimen on prognosis of osteosarcoma: A systematic review and meta-analysis of 16 studies. Medicine 2016, 95, e3661. [CrossRef]

100. Abdou, A.G.; Kandil, M.; Asaad, N.Y.; Dawoud, M.M.; Shahin, A.A.; Abd Eldayem, A.F. The Prognostic Role of Ezrin and HER2/neu Expression in Osteosarcoma. Appl. Immunohistochem. Mol. Morphol. AIMM 2016, 24, 355-363. [CrossRef]

101. Chen, C.; Constantinou, A.; Chester, K.A.; Vyas, B.; Canis, K.; Haslam, S.M.; Dell, A.; Epenetos, A.A.; Deonarain, M.P. Glycoengineering approach to half-life extension of recombinant biotherapeutics. Bioconjug. Chem. 2012, 23, 1524-1533. [CrossRef]

102. Wunder, J.S.; Lee, M.J.; Nam, J.; Lau, B.Y.; Dickson, B.C.; Pinnaduwage, D.; Bull, S.B.; Ferguson, P.C.; Seto, A.; Gokgoz, N.; et al Osteosarcoma and soft-tissue sarcomas with an immune infiltrate express PD-L1: Relation to clinical outcome and Th1 pathway activation. Oncoimmunology 2020, 9, 1737385. [CrossRef]

103. Hashimoto, K.; Nishimura, S.; Akagi, M. Characterization of PD-1/PD-L1 Immune Checkpoint Expression in Osteosarcoma. Diagnostics 2020, 10, 528. [CrossRef]

104. Liu, P.; Xiao, Q.; Zhou, B.; Dai, Z.; Kang, Y. Prognostic Significance of Programmed Death Ligand 1 Expression and TumorInfiltrating Lymphocytes in Axial Osteosarcoma. World Neurosurg. 2019, 129, e240-e254. [CrossRef]

105. Gomez-Brouchet, A.; Illac, C.; Gilhodes, J.; Bouvier, C.; Aubert, S.; Guinebretiere, J.M.; Marie, B.; Larousserie, F.; Entz-Werlé, N.; de Pinieux, G.; et al. CD163-positive tumor-associated macrophages and CD8-positive cytotoxic lymphocytes are powerful diagnostic markers for the therapeutic stratification of osteosarcoma patients: An immunohistochemical analysis of the biopsies fromthe French OS2006 phase 3 trial. Oncoimmunology 2017, 6, e1331193. [CrossRef]

106. Torabi, A.; Amaya, C.N.; Wians, F.H., Jr.; Bryan, B.A. PD-1 and PD-L1 expression in bone and soft tissue sarcomas. Pathology 2017, 49, 506-513. [CrossRef] [PubMed]

107. Majzner, R.G.; Simon, J.S.; Grosso, J.F.; Martinez, D.; Pawel, B.R.; Santi, M.; Merchant, M.S.; Geoerger, B.; Hezam, I.; Marty, V.; et al. Assessment of programmed death-ligand 1 expression and tumor-associated immune cells in pediatric cancer tissues. Cancer 2017, 123, 3807-3815. [CrossRef] [PubMed]

108. Liao, Y.; Chen, L.; Feng, Y.; Shen, J.; Gao, Y.; Cote, G.; Choy, E.; Harmon, D.; Mankin, H.; Hornicek, F.; et al. Targeting programmed cell death ligand 1 by CRISPR/Cas9 in osteosarcoma cells. Oncotarget 2017, 8, 30276-30287. [CrossRef]

109. Koirala, P.; Roth, M.E.; Gill, J.; Piperdi, S.; Chinai, J.M.; Geller, D.S.; Hoang, B.H.; Park, A.; Fremed, M.A.; Zang, X.; et al. Immune infiltration and PD-L1 expression in the tumor microenvironment are prognostic in osteosarcoma. Sci. Rep. 2016, 6, 30093. [CrossRef]

110. Kalim, M.; Wang, S.; Liang, K.; Khan, M.S.I.; Zhan, J. Engineered scPDL1-DM1 drug conjugate with improved in vitro analysis to target PD-L1 positive cancer cells and intracellular trafficking studies in cancer therapy. Genet. Mol. Biol. 2020, 42, e20180391. [CrossRef]

111. Rouleau, C.; Curiel, M.; Weber, W.; Smale, R.; Kurtzberg, L.; Mascarello, J.; Berger, C.; Wallar, G.; Bagley, R.; Honma, N.; et al. Endosialin protein expression and therapeutic target potential in human solid tumors: Sarcoma versus carcinoma. Clin. Cancer Res. Off. J. Am. Assoc. Cancer Res. 2008, 14, 7223-7236. [CrossRef]

112. Lange, S.E.; Zheleznyak, A.; Studer, M.; O'Shannessy, D.J.; Lapi, S.E.; Van Tine, B.A. Development of 89Zr-Ontuxizumab for in vivo TEM-1/endosialin PET applications. Oncotarget 2016, 7, 13082-13092. [CrossRef]

113. Gupta, S.; Sosa, C.P.; Kosari, F.; Folpe, A.; Bhinge, K.N.; Yang, L.; Agahi, A.; Johnson, S.H.; Frank, I.; Boorjian, S.A.; et al. A comparison of adult rhabdomyosarcoma and high-grade neuroendocrine carcinoma of the urinary bladder reveals novel PPP1R12A fusions in rhabdomyosarcoma. Hum. Pathol. 2019, 88, 48-59. [CrossRef] [PubMed]

114. Sadikovic, B.; Graham, C.; Ho, M.; Zielenska, M.; Somers, G.R. Immunohistochemical expression and cluster analysis of mesenchymal and neural stem cell-associated proteins in pediatric soft tissue sarcomas. Pediatr. Dev. Pathol. Off. J. Soc. Pediatr. Pathol. Paediatr. Pathol. Soc. 2011, 14, 259-272. [CrossRef] [PubMed] 
115. Bahrami, A.; Gown, A.M.; Baird, G.S.; Hicks, M.J.; Folpe, A.L. Aberrant expression of epithelial and neuroendocrine markers in alveolar rhabdomyosarcoma: A potentially serious diagnostic pitfall. Mod. Pathol. 2008, 21, 795-806. [CrossRef] [PubMed]

116. Mechtersheimer, G.; Staudter, M.; Möller, P. Expression of the natural killer cell-associated antigens CD56 and CD57 in human neural and striated muscle cells and in their tumors. Cancer Res. 1991, 51, 1300-1307. [PubMed]

117. Thompson, L.D.R.; Jo, V.Y.; Agaimy, A.; Llombart-Bosch, A.; Morales, G.N.; Machado, I.; Flucke, U.; Wakely, P.E., Jr.; Miettinen, M.; Bishop, J.A. Sinonasal Tract Alveolar Rhabdomyosarcoma in Adults: A Clinicopathologic and Immunophenotypic Study of Fifty-Two Cases with Emphasis on Epithelial Immunoreactivity. Head Neck Pathol. 2018, 12, 181-192. [CrossRef]

118. Karakuş, R.; Karakuş, E.; Emir, S.; Kaçar, A.; Özyörük, D. Insulin-like growth factor-1 receptor expression in pediatric tumors: A comparative immunohistochemical study. Turk. J. Med. Sci. 2018, 48, 419-423. [CrossRef]

119. van Gaal, J.C.; Roeffen, M.H.; Flucke, U.E.; van der Laak, J.A.; van der Heijden, G.; de Bont, E.S.; Suurmeijer, A.J.; Versleijen-Jonkers, Y.M.; van der Graaf, W.T. Simultaneous targeting of insulin-like growth factor-1 receptor and anaplastic lymphoma kinase in embryonal and alveolar rhabdomyosarcoma: A rational choice. Eur. J. Cancer 2013, 49, 3462-3470. [CrossRef]

120. Miyoshi, K.; Kohashi, K.; Fushimi, F.; Yamamoto, H.; Kishimoto, J.; Taguchi, T.; Iwamoto, Y.; Oda, Y. Close correlation between CXCR4 and VEGF expression and frequent CXCR7 expression in rhabdomyosarcoma. Hum. Pathol. 2014, 45, 1900-1909. [CrossRef]

121. Krawczyk, M.A.; Styczewska, M.; Sokolewicz, E.M.; Kunc, M.; Gabrych, A.; Fatyga, A.; Izycka-Swieszewska, E.; Kazanowska, B.; Adamkiewicz-Drozynska, E.; Bien, E. Tumour expressions of hypoxic markers predict the response to neo-adjuvant chemotherapy in children with inoperable rhabdomyosarcoma. Biomark. Biochem. Indic. Expo. Response Susceptibility Chem. 2019, 24, 538-548. [CrossRef]

122. Kendsersky, N.M.; Lindsay, J.; Kolb, E.A.; Smith, M.A.; Teicher, B.A.; Erickson, S.W.; Earley, E.J.; Mosse, Y.P.; Martinez, D.; Pogoriler, J.; et al. The B7-H3-Targeting Antibody-Drug Conjugate m276-SL-PBD Is Potently Effective Against Pediatric Cancer Preclinical Solid Tumor Models. Clin. Cancer Res. Off. J. Am. Assoc. Cancer Res. 2021, 27, 2938-2946. [CrossRef]

123. Thway, K.; Robertson, D.; Jones, R.L.; Selfe, J.; Shipley, J.; Fisher, C.; Isacke, C.M. Endosialin expression in soft tissue sarcoma as a potential marker of undifferentiated mesenchymal cells. Br. J. Cancer 2016, 115, 473-479. [CrossRef]

124. Freise, A.C.; Wu, A.M. In vivo imaging with antibodies and engineered fragments. Mol. Immunol. 2015, 67, 142-152. [CrossRef]

125. Van Leeuwen, F.W.B.; Schottelius, M.; Brouwer, O.R.; Vidal-Sicart, S.; Achilefu, S.; Klode, J.; Wester, H.J.; Buckle, T. Trending: Radioactive and Fluorescent Bimodal/Hybrid Tracers as Multiplexing Solutions for Surgical Guidance. J. Nucl. Med. 2020, 61, 13-19. [CrossRef]

126. Folli, S.; Wagnières, G.; Pèlegrin, A.; Calmes, J.M.; Braichotte, D.; Buchegger, F.; Chalandon, Y.; Hardman, N.; Heusser, C.; Givel, J.C.; et al. Immunophotodiagnosis of colon carcinomas in patients injected with fluoresceinated chimeric antibodies against carcinoembryonic antigen. Proc. Natl. Acad. Sci. USA 1992, 89, 7973-7977. [CrossRef]

127. Hekman, M.C.; Rijpkema, M.; Muselaers, C.H.; Oosterwijk, E.; Hulsbergen-Van de Kaa, C.A.; Boerman, O.C.; Oyen, W.J.; Langenhuijsen, J.F.; Mulders, P.F. Tumor-targeted Dual-modality Imaging to Improve Intraoperative Visualization of Clear Cell Renal Cell Carcinoma: A First in Man Study. Theranostics 2018, 8, 2161-2170. [CrossRef] [PubMed]

128. Kuil, J.; Velders, A.H.; van Leeuwen, F.W. Multimodal tumor-targeting peptides functionalized with both a radio- and a fluorescent label. Bioconjug. Chem. 2010, 21, 1709-1719. [CrossRef] [PubMed]

129. Hensbergen, A.W.; Buckle, T.; van Willigen, D.M.; Schottelius, M.; Welling, M.M.; van der Wijk, F.A.; Maurer, T.; van der Poel, H.G.; van der Pluijm, G.; van Weerden, W.M.; et al. Hybrid Tracers Based on Cyanine Backbones Targeting Prostate-Specific Membrane Antigen: Tuning Pharmacokinetic Properties and Exploring Dye-Protein Interaction. J. Nucl. Med. 2020, 61, 234-241. [CrossRef] [PubMed]

130. Jacob, F.; Salinas, R.D.; Zhang, D.Y.; Nguyen, P.T.T.; Schnoll, J.G.; Wong, S.Z.H.; Thokala, R.; Sheikh, S.; Saxena, D.; Prokop, S.; et al. A Patient-Derived Glioblastoma Organoid Model and Biobank Recapitulates Inter- and Intra-tumoral Heterogeneity. Cell 2020, 180, 188-204.e122. [CrossRef] [PubMed]

131. Kopper, O.; de Witte, C.J.; Lõhmussaar, K.; Valle-Inclan, J.E.; Hami, N.; Kester, L.; Balgobind, A.V.; Korving, J.; Proost, N.; Begthel, H.; et al. An organoid platform for ovarian cancer captures intra- and interpatient heterogeneity. Nat. Med. 2019, 25, 838-849. [CrossRef] [PubMed] 